\title{
Dogri Language
}

National Cancer Institute

\section{Source}

National Cancer Institute. Dogri Language. NCI Thesaurus. Code C153902.

An Indo-Aryan language spoken in India and Pakistan, chiefly in the Jammu region. 